NBER WORKING PAPER SERIES

\title{
WHY DOES CAPITAL FLOW TO RICH STATES?
}

Sebnem Kalemli-Ozcan

Ariell Reshef

Bent Sorensen

Oved Yosha

Working Paper 11301

http://www.nber.org/papers/w11301

\section{NATIONAL BUREAU OF ECONOMIC RESEARCH \\ 1050 Massachusetts Avenue \\ Cambridge, MA 02138 \\ May 2005}

(C) 2005 by Sebnem Kalemli-Ozcan, Ariell Reshef, Bent Sorensen, and Oved Yosha. All rights reserved. Short sections of text, not to exceed two paragraphs, may be quoted without explicit permission provided that full credit, including $(C$ notice, is given to the source. 
Why Does Capital Flow to Rich States?

Sebnem Kalemli-Ozcan, Ariell Reshef, Bent Sorensen, and Oved Yosha

NBER Working Paper No. 11301

May 2005, Revised February 2009

JEL No. F21,F41

\title{
$\underline{\text { ABSTRACT }}$
}

The magnitude and the direction of net international capital flows does not fit neo-, classical models. The 50 U.S. states comprise an integrated capital market with very, low barriers to capital flows, which makes them an ideal testing ground for neoclassical, models. We develop a simple frictionless open economy model with perfectly diversified, ownership of capital and find that capital flows between the U.S. states are consistent, with the model. Therefore, the small size and "wrong" direction of net international, capital flows are likely due to frictions associated with national borders and not due, to inherent flaws in the neoclassical model.

\author{
Sebnem Kalemli-Ozcan \\ Bent Sorensen \\ University of Houston \\ Department of Economics \\ Department of Economics \\ University of Houston \\ Houston, TX 77204 \\ 204 McElhinney Hall \\ and NBER \\ Houston, TX 77204 \\ sebnem.kalemli-ozcan@mail.uh.edu \\ bent.sorensen@mail.uh.edu \\ Ariell Reshef \\ Oved Yosha \\ University of Virginia \\ Department of Economics \\ 2015 Ivy Rd., Room 312 \\ Charlottesville, VA 22903 \\ ariellr@virginia.edu
}




\section{Introduction}

International capital flows have surged since the early 1990s, creating renewed interest in their determinants. One salient fact of this recent increase is the small size of net capital flows relative to gross flows. ${ }^{1}$ In addition, capital has flowed "uphill" from poorer to richer countries in the last decade, a phenomenon that has manifested itself in recent global imbalances. $^{2}$ These empirical patterns are at odds with theoretical benchmarks. The goal of this paper is to demonstrate the viability of the simple neoclassical model in the ideal setting of fully integrated economies such as the 50 U.S. states. We develop a frictionless open economy neoclassical model where capital income is fully diversified and show that it fits the data for U.S. states well, both qualitatively and quantitatively.

The key elements of our model are as follows. Capital income-but not labor income - is

fully diversified between states and total factor productivity (TFP) varies across states and over time. ${ }^{3}$ We assume that capital markets are fully integrated in the sense that individuals can borrow and lend freely across state borders and insure themselves against state-specific risk by holding a geographically diversified portfolio of assets. Hence, relative investment is determined by relative productivity levels and relative savings do not play any role in determining relative investment. The model predicts that capital will flow to fast growing states from slow growing states and as a result high growth states pay capital income to other states. ${ }^{4}$ With persistent productivity shocks, high output_ - "rich" — states end up being net debtors more often than not.

Our model delivers the following predictions: 1) income increases less than output in 
high growth states, 2) net dividends converge to zero in the absence of growth shocks, and 3) high output states tend to pay net dividends. We simulate the model in order to obtain quantitative predictions and then verify that these results hold using U.S. statelevel data. Consequently, we conclude that the main explanation for the small size and "wrong" direction of international capital flows is more likely due to "frictions" associated with national borders - making international financial markets de facto incomplete - rather than to inherent deficiencies in the simple neoclassical model. ${ }^{5}$

Testing the implications of the model in a regression framework requires data on interstate net capital flows. We do not have data on state-level current accounts, but income flows ("dividends") between states typically reflect past net investment flows. However, dividend payments between states are not directly observed either. In the country-level national accounts net capital income flows are approximately equal to the difference between Gross National Income ("income") and Gross Domestic Product ("output"). ${ }^{6}$ Output is observed for U.S. states but the state-level equivalent of GNI is not. We use approximations to statelevel GNI based on observed state-level personal income. Thus, the ratio of output to income ("output/income") is an indicator of net capital income. When the ratio is larger than one, this indicates a net capital income outflow. We derive the predictions of the model for the output/income ratio and test these predictions.

The output/income ratio has been used before to infer past net capital flows between U.S. states by Atkeson and Bayoumi (1993a,b) who found large inter-regional net capital flows within the United States. However, they did not systematically match their findings 
to a model nor did they study the determinants of state-level capital flows. Of particular relevance is their finding that personal dividend income is highly correlated across states, consistent with our assumption that capital ownership is diversified geographically. ${ }^{7}$

The surge in international asset trade has triggered recent research efforts focussing on portfolio models of the current account. Starting with the partial equilibrium approach of Kraay and Ventura (2000), this literature highlights the importance of countries' net external positions in determining current account balances and hence the pattern of capital flows. A central result, which has been a source of controversy, is that countries hold a constant ratio of domestic to foreign capital. ${ }^{8}$ We contribute to this debate as our model and empirical results show that portfolio shares follow a mean-reverting process.

In the next section, we derive and simulate theoretical predictions. Section 3 performs the empirical analysis. Section 4 concludes the paper.

\section{Capital Flows in a Neoclassical Growth Model}

Consider states $i=1, \ldots, N$, with labor force $L_{i t}$. Output at time $t$ is given by $G D P_{i t}=$ $A_{i t} K_{i t}^{\alpha} L_{i t}^{1-\alpha}$, where $K_{i t}$ is capital in state $i$ and $0<\alpha<1$. We denote the aggregate capital stock by $K_{t}$. State $i$ 's ownership share is $\phi_{i t}$, so that assets owned by state $i$ are $\phi_{i t} K_{t}$ with $\sum_{i=1}^{N} \phi_{i t}=1$, where the last equality follows from the assumption that the United States is a closed economy. ${ }^{9}$ We can, therefore, also think of $K_{t}$ as the value of a U.S.-wide mutual fund.

Under market integration the ex ante gross rate of return to investment is $R_{t}$ for all 
states - in our simulations, $R_{t}$ will be the equilibrium market clearing rate of interest. We assume that capital ownership is fully diversified and risk premiums are negligible. Therefore, capital will flow to state $i$ until the marginal return to capital equals the U.S.-wide gross

interest rate $R_{t}$; i.e., $R_{t}=\alpha A_{i t} K_{i t}^{\alpha-1} L_{i t}^{1-\alpha}, \quad \forall i, t$, which implies $K_{i t}=L_{i t}\left(\frac{\alpha A_{i t}}{R_{t}}\right)^{\frac{1}{1-\alpha}}$. The gross income of the U.S.-wide mutual fund is $R_{t} K_{t}$ and the wage rate in state $i$ is $w_{i t}=$ $(1-\alpha) A_{i t} K_{i t}^{\alpha} L_{i t}^{-\alpha}$. Therefore, gross (pre-depreciation) income, GNI, in state $i$ is $G N I_{i t}=$ $\phi_{i t} R_{t} K_{t}+w_{i t} L_{i t}=\phi_{i t} R_{t} K_{t}+(1-\alpha) A_{i t} K_{i t}^{\alpha} L_{i t}^{1-\alpha}$ and the output/income (GDP/GNI) ratio is

$$
\frac{G D P_{i t}}{G N I_{i t}}=\frac{A_{i t} K_{i t}^{\alpha} L_{i t}^{1-\alpha}}{\phi_{i t} R_{t} K_{t}+(1-\alpha) A_{i t} K_{i t}^{\alpha} L_{i t}^{1-\alpha}}=\frac{G D P_{i t}}{\phi_{i t} R_{t} K_{t}+(1-\alpha) G D P_{i t}} .
$$

The output/income ratio measures the relative magnitude of net inter-state capital income flows from a state. If such flows are zero, the ratio is unity; if they are negative, the ratio is less than unity; and if they are positive, the ratio exceeds unity.

Equation (1) implies that the output/income ratio is a function of output and capital ownership. Another implication of equation (1), under the assumption that growth in state $i$ will not affect $R_{t} K_{t}$, is that

$$
d\left(\frac{G D P_{i t}}{G N I_{i t}}\right) \approx \alpha \frac{d G D P_{i t}}{G D P_{i t}},
$$

where the derivative is evaluated at the point $G N I_{i t}=G D P_{i t}$.

\section{Dynamics of Ownership}

The law of motion for capital is $K_{t+1}=(1-\delta) K_{t}+s G N I_{t}$ where $s G N I_{t}$ is gross savings, 
$s$ is the savings rate, and $\delta$ is the depreciation rate. The stock of capital owned by state $i$ in period $t+1$ is $\phi_{i t} K_{t}(1-\delta)+s G N I_{i t}$ and the law of motion for the ownership share is

$$
\phi_{i t+1}=\frac{\phi_{i t} K_{t}(1-\delta)+s G N I_{i t}}{K_{t}(1-\delta)+s G N I_{t}}
$$

In the absence of productivity shocks, with equal populations and productivity levels, the portfolio shares revert to the mean of $1 / N$ and hence the GDP/GNI ratio reverts to 1 over time, assuming that the saving rate is constant across states. The mechanism is given as follows: consider a state with a one-time positive productivity shock. This state will see output increase more than income, but because wages will be higher than in other states, savings will also be higher. The higher savings will result in higher asset income in the following period and the result is gradual convergence of the level of income to the new output level.

\section{Workers and Stock Holders}

Not all workers hold assets and some asset holders are not workers (in particular, retirees). We can predict the marginal impact on the output/income ratio of a change in the number of workers (without assets) or a change in the number of "stock holders" (asset holders) by taking derivatives. Consider the symmetric case $G D P_{i t}=G D P_{t} \frac{L_{i t}}{L_{t}}$ and assume that the number of shareholders in state $i$ is $S_{i t}$ with $\Sigma S_{i t}=S_{t} .{ }^{10}$ We evaluate the derivative under the assumption that each shareholder owns $K_{t} / S_{t}$ shares and the number of shareholders varies by state. In this case, the ownership share of state $i$ is equal to the fraction of U.S. 
stock-holders in state $i$, and we get

$$
\frac{G D P_{i t}}{G N I_{i t}}=\frac{\frac{L_{i t}}{L_{t}} G D P_{t}}{\frac{S_{i t}}{S_{t}} \alpha G D P_{t}+(1-\alpha) \frac{L_{i t}}{L_{t}} G D P_{t}} .
$$

We can find the predicted change in the output/income ratio at the point $L_{t}=S_{t}$ (implying an output/income ratio of $\left.\frac{1}{\alpha \frac{S_{i t}}{L_{i t}}+(1-\alpha)}\right)$ by taking the differential. We find

$$
d\left(\frac{G D P_{i t}}{G N I_{i t}}\right) \approx \alpha \frac{d G D P_{i t}}{G D P_{i t}}-\alpha \frac{d S_{i t}}{L_{i t}}+\alpha \frac{d L_{i t}}{L_{i t}},
$$

where the first term is a repetition of equation (2).

\subsection{Comments on the Model}

Our model is a dynamic stochastic general equilibrium model albeit the assumption of constant savings rates renders it particularly simple to solve. Our goal is to demonstrate that a bare-bones neoclassical model fits the U.S. data well. A more complicated model might do an even better job, but we are constrained by the availability of data. In this section, we discuss three central issues, namely saving, productivity, and capital reallocation.

As an empirical matter, reliable estimates of state-level savings are hard to come by. Therefore we prefer not to condition our predictions on models of saving. According to permanent income theory, individuals save a smaller fraction of their income the higher the expected present value of future income shocks. As argued by Glick and Rogoff (1995), the intertemporal approach to the current account implies that following a "permanent" country- 
specific shock, there will be a current account deficit at least as large as the corresponding rise in investment. Using international data they regress changes in gross investment and current accounts on the changes in TFP and find that gross investment reacts stronger than the current account which is at odds with theory under the assumption of perfect capital mobility and existence of persistent productivity shocks. ${ }^{11}$ However, the response of savings can be justified by productivity shocks that are slowly mean reverting rather than permanent. $^{12}$

In our model, because of full diversification and hence no risk premia, relative investment will be determined by relative productivity with no role for state-specific savings rates. Hence, both debtor and creditor countries can attract capital on net and run current account deficits if they are hit by positive persistent productivity shocks. If capital flows to high growth regions we should, everything else equal, see that high output regions run current account deficits and hold negative net asset positions. ${ }^{13}$ Sometimes poorer regions appear to be in the "catch-up growth" phase where they grow relatively fast and attract capital from other regions; an example is the U.S. southern states in the 1950s. ${ }^{14}$

We now turn to discuss productivity. TFP shocks are the fundamental drivers in our model although, in our empirical work, a strict technology interpretation of TFP shocks is misleading and TFP should be interpreted very broadly. ${ }^{15}$ In particular, relative price changes, such as oil price shocks that increase the return to capital in oil-rich states, are an important source of TFP variation, broadly defined, in our data. The crucial condition behind our results is that capital will flow to a region until the marginal return $\alpha A_{i t} K_{i t}^{\alpha-1} L_{i t}^{1-\alpha}$ 
exceeds $R_{t}$. For example, consider a case with no literal technology shocks, where consumers in all states consume the same consumption basket, and the relative price of output sold by state $i$ in the U.S.-wide markets is $p_{i t}$. In this case, capital will flow to state $i$ until $\alpha p_{i t} K_{i t}^{\alpha-1} L_{i t}^{1-\alpha}$ equals $R_{t}$.

We do not imagine machines being dismantled and carted to other states; rather, we imagine that net investment is higher in states with high TFP and that this can be modeled as malleable capital when long time intervals are considered. This approach is supported by Blomstrom et al. (1996), who perform Granger causality tests and show that growth induces subsequent capital formation more than capital formation induces subsequent growth at the country level. ${ }^{16}$

\subsection{Regressions with Simulated Data}

In order to evaluate the quantitative predictions of the model, we simulate it for $\mathrm{N}=50$ open economies, "states," for $\mathrm{T}=100$ periods (corresponding to years) using a Cobb-Douglas production function with capital's share, $\alpha=0.33$. We set $L_{i t}=1$ for all states $i$ and periods $t$. For the productivity process, we assume

$$
\log \left(A_{i t}\right)=(1-\rho) \log \left(A_{0}\right)+\rho \log \left(A_{i t-1}\right)+\sigma \epsilon_{i t},
$$

where $\epsilon$ is a standard normal innovation, independent across states and periods.

The equilibrium $R_{t}$ satisfies $\Sigma_{i=1}^{50}\left(\frac{\alpha A_{i t}}{R_{t}}\right)^{\frac{1}{1-\alpha}}=K_{t}$, where $K_{t}$ is determined at $t-1$ and we get $K_{i t}=\left(\frac{\alpha A_{i t}}{R_{t}}\right)^{\frac{1}{1-\alpha}}$. Having found $K_{i t}$, we find $w_{i t}=(1-\alpha) A_{i t} K_{i t}^{\alpha}$ and calculate 
$G N I_{i t}=w_{i t}+\phi_{i t} R_{t} K_{t}$. Aggregate $G N I_{t}\left(=G D P_{t}\right)$ is then found as $G N I_{t}=\Sigma_{i=1}^{50} G N I_{i t}$. Finally, we use equation (3) to calculate $\phi_{i t+1}$.

To initialize the process we choose an arbitrary $K_{0}$ and simulate the model for a number of years until it converges to a steady-state value. We set the initial level of productivity in each state $A_{0}=1$ (a normalization) and the initial ownership share of each state $\phi_{i 0}=1 / 50$. For the parameters that govern the productivity process, we choose $\rho=0.99$ and $\sigma=0.02$. The standard deviation of productivity is chosen to generate state-level output volatility that match the observed volatility in the data. We use $s=0.20$ and $\delta=0.05$. The calibration of these parameter values is guided by aggregate and state-specific data moments.

We perform cross-sectional regressions using the simulated values for 50 states. We perform 2 sets of regressions. "Change regressions" consider the change in the output/income ratio as a function of growth. These regressions are motivated by equation (2) which predict a clear relationship between the change in the output/income ratio and output growth. This relationship is the sharpest prediction of the model as it involves only observable variables. We also estimate "level regressions," where we consider the relationship of the output/ratio to past output and ownership, motivated by equation (1). Because ownership shares are not observed the empirical predictions are less sharp and simulations are needed in order to find quantitative implications.

We performed 200 regressions (from 200 simulations) and report the average coefficients and the standard deviations across the 200 simulations. Table 1 shows the results of a regression of the change in the (decade average) output/income ratio from the second-to-last 
decade to the last decade regressed on growth in output over the second to last decade. These "years" are chosen to match the empirical regressions in Table 5. (The choice of specification is discussed in the empirical section below.) We consider the predicted coefficients for changes the more important implications of our model. For instantly observed changes our model predicts a coefficient near 0.33 but here we find a significant coefficient of 0.08 - the passing of time results in a smaller coefficient. Column (2) adds the output/income ratio of the previous decade. We find a coefficient of 0.13 to growth and a coefficient to the lagged output income ratio of -0.44 . This implies a half-life for output/income deviations (from the average of unity) of about 15 years.

Table 2, column (1), displays results from regressing the log average output/income ratio in the last 20 years on log average output from the 4 preceding years. (As before "years" are chosen to match the empirical regressions in Table 7.) We find a statistically significant coefficient of 0.05 implying that high output states have higher output than income and, therefore, are net recipient of out-of-state capital. In other words, capital flows to "rich" states on average. In column (2), we add the lagged log-ownership share. In the actual data as well as in the simulated data, high output regions tend to have high ownership shares, so to limit collinearity, we use ownership shares that are averaged over data five "decades" ago. ${ }^{17}$ We get a negative significant coefficient of -0.14 , implying that states with an ownership share 1 percent above average will tend have an output/income ratio 0.14 percent below average 50 years later.

We performed sensitivity analysis by changing parameter values and initial arbitrary 
values. Overall, the results are qualitatively robust-in particular, the results of the change regressions are very robust. The level regressions are somewhat sensitive to the size of the productivity shocks (the larger shocks, the larger the coefficient to lagged output in Table 2) and the depreciation rate (typically, smaller coefficients with high depreciation).

\section{Empirical Analysis}

The raw data series were obtained from the Bureau of Economic Analysis (BEA), unless otherwise stated. All nominal variables are converted into 2000 prices using the consumer price index. ${ }^{18}$ We provide a detailed description of the variables in the data appendix.

State-level GDP, denoted Gross State Product (GSP), is published by the BEA as part of the U.S. state-level national accounts. GSP is defined as the sum of value added originating in all industries in the state; thus, it is exactly the state-level equivalent of GDP. GSP numbers are based on income generated in establishments and the main sources are industrial censuses such as the census of manufactures. GSP is available for the years 1977-2000. Previously published, but no longer updated by the BEA, GSP data is available since 1963, but that data is not fully compatible with the data post 1977 and hence we use this data only in a descriptive sense.

Our main measure for income is State Personal Income (SPI), which is based mainly on administrative-records data and on data from censuses and surveys. SPI is derived by adding personal earnings, government transfers and dividend, interest and rental income and subtracting contributions to government social insurance. While it might seem preferable 
to use approximate GNI numbers for easier comparison to country-level data, we prefer to focus on the results based on simple SPI since a large number of imputations are needed to approximate of GNI. In the appendix we show the relationship between GNI and GDP in the aggregate U.S. National Income and Product Accounts. We discuss the calculation of GSP and SPI in detail as well as several approximations to GNI that are used to demonstrate robustness of our results to different calculations of "income."

\subsection{The Empirical Output/Income Ratio}

We calculate the output/income ratio for each U.S. state, year-by-year, which allows us to study the patterns of inter-state capital income flows over time. The variables SPI and GSP contain aggregate (U.S.-wide) components - in particular, the burgeoning U.S. balance-of-

payments deficits - that may vary over time and affect the output/income ratio for individual states. These aggregate effects are not of interest to us in the context of inter-state capital mobility. To correct for this, we normalize the output/income ratio:

$$
{\text { Output } / \text { Income }_{i t}}=\frac{\operatorname{GSP}_{i t} / \mathrm{SPI}_{i t}}{\mathrm{GSP}_{t} / \mathrm{SPI}_{t}}
$$

where

$$
\mathrm{SPI}_{t}=\Sigma_{i} \mathrm{SPI}_{i t}, \quad \mathrm{GSP}_{t}=\Sigma_{i} \mathrm{GSP}_{i t}
$$

The ratio Output/Income $i t$ captures state $i$ 's output/income ratio in year $t$ relative to the aggregate U.S. output/income ratio. 


\subsection{Graphical Evidence: 1963-2000}

Figure 1 shows the output/income ratio and the growth rates for eight U.S. Census regions relative to the average (normalized to unity) across states. We aggregate to regions in order to get a manageable amount of graphs. The Southwest region had relatively high growth in the 1960s while the Great Lakes and New England regions had relatively low growth. For New England, this situation rapidly reversed in the 1980s while the Great Lakes regions only slowly recovered to reach the middle of the field by year 2000. The figure also reveals that New England, the Mid East, and the Great Lakes regions consistently have lower output than income, while other regions exhibit higher output than income. The general pattern corresponds well with the historical pattern of high output and income in the central and Northeastern states around the turn of the century — see North (1961). Part of this income is likely to have been invested in other regions, resulting in capital income flows from those regions in the later part of the 20th century.

A significant change in the output/income ratio relative to other regions is found for the Great Lakes. This region saw a steady decrease in the ratio throughout the 1960s and 1970s moving from above to below average. ${ }^{19}$ Another significant change is the decline in the output/income ratio for the Southwest at the same time as the output/income ratio increased in New England. These patterns are exactly what our model would predict, conditional on the growth patterns. The Great Lakes region throughout our sample was a laggard in terms of relative growth. This region should, according to our model, have been a net supplier of capital to other regions and, consequently, have experienced a slowly declining 
output/income ratio - exactly as we observe. New England, on the other hand, experienced a rapid reversal of fortune in output growth in the 1980s (the "Massachusetts miracle") and the output/income ratio of New England increased rapidly. The pattern for the Southwest is the opposite of that found for New England which is also consistent with our model.

The large changes in oil prices that occurred during the period 1973-74 and 1979-87 are clearly visible in Figure 1. The output/income ratio of the Southwest region, which contains most of the major oil-producing states, increases due to the oil price hikes in the 1970s and then declines steeply in the years following the Iranian revolution in 1979.

Figure 2 explores directly if oil price spikes were reflected in changes in the output/income ratio for states with high output of oil ("oil-states"). We plot the average world price of crude oil and the average output/income ratio for the oil-states Alaska, Louisiana, and Wyoming for the years 1963-2000. There is a clear pattern with the output/income ratio increasing following (with about a three years lag) increases in the price of oil and vice versa when the oil price falls. This pattern is consistent with oil exploration having been financed by other states which in periods of high oil prices receive relatively higher factor income from the oil states.

[FIGURE 1 HERE]

[FIGURE 2 HERE]

The graphical evidence reflects the historical developments document by Romans (1965). He constructs state-level "current accounts" for U.S. states for 1953 and 1957 and finds that investment minus saving (i.e., net capital inflows) was very large and positive for southern 
states and oil states in the 1950s. ${ }^{20}$ One may notice from Figure 1 that even during the period of the mid-1980s where the growth rate of New England was about twice the national average, the output/income ratio for New England stayed below unity. This is consistent with our model when net capital flows are large and New England was a net supplier of capital to other states in the 1950s and remained a net creditor at the beginning of the 1980s (corresponding to an above average value of $\phi_{i}$ in the model).

In agreement with our model, states with large negative values of saving minus investment in the 1950s tend to be the states with high output/income ratios in the 1980s and 1990s, as shown by Kalemli-Ozcan, Turan, and Sørensen (2008), who also argue that the "catch up" growth of the 1950s and 1960s mainly was over by the late 1980s.

\subsection{Specification of Regressions}

We estimate specifications similar to those of Tables 1 and 2 using actual data. ${ }^{21}$ We fit cross-sectional regressions to data averaged over long time spans in order to minimize the potential effects of business cycles and measurement errors. In choosing the interval length we face a trade-off. For long enough intervals, adjustment costs in investments can be taken to be negligible and business cycle effects will average out. ${ }^{22}$ However, even if there is ample evidence that (relative) productivity shocks are persistent, these shocks do not last forever and we may obtain higher variation in growth rates if we consider shorter intervals.

The main regressors for the change regressions are output growth, the lagged output/income ratio, and growth of population and retirees. Ideally, we would like to include 
stock-holders but retirees are, per definition, not in the labor force and, usually, hold assets. Based on equation (5) we expect that the output/income ratio changes with the normalized number of retirees at a similar rate as it changes with growth, albeit with a negative sign. ${ }^{23}$

Our model is couched in terms of stock holders with average assets and labor force with no assets but the data does not provide such details. However, differences in population growth are mainly due to migrants and migration (especially when controlling in the regressions for the number of retirees) is dominated by young workers without assets. Therefore, based on equation (5), we expect the output/income ratio to change with migration with a proportionality factor similar to that of growth and with an identical sign. ${ }^{24}$ However, if migrants bring some assets the coefficient will be smaller - if migrants bring average assets the coefficient to population growth would be near zero. Similarly, if retirees hold less assets than the average individual we would expect a coefficient smaller than that of growth and vice versa if retirees hold more assets. ${ }^{25}$

For the level regressions the main regressor is lagged output per capita. Reliable measures of net ownership are not available, so we examine whether indicators of historical wealth predict current output/income ratios. As our measure of historical wealth, we use the logarithm of the per capita value of dividend and interest income by state, averaged over 1939-1949. ${ }^{26}$ We have access to this data since 1929 and we prefer values that are distant from the income data used to calculate the current output/income ratio and not too close to the 1977-1980 period to avoid high collinearity with the output data. For that reason, and in order to avoid the financial upheavals of the Great Depression, we chose the 1939-1949 
sample. The results are not very sensitive to exactly which sample is chosen, except that the coefficient to this variable is smaller if we use the data from the 1930s.

We include other controls that are not present in the model, but are important in reality: oil deposits are highly concentrated in relatively few states that likely obtain a large fraction of the required capital from outside sources - this is most clearly observed in Alaska where the large multinational oil companies have made large investments. ${ }^{27}$ We do not have direct measures of the value of natural endowments of oil and minerals, so we approximate it for each state by the share of the gross product of the oil and mineral extraction sector in total GSP averaged over averaged over 1977-1980. In order to dampen the impact of outliers, we use the transformation $\log (1+x)$ for the oil share. As a measure of the number of retirees, we use the share of residents aged 65 and above.

\subsection{Descriptive Statistics}

In Table 3, we tabulate per capita dividend and interest income by state averaged over 1939-1949 (no data available for Hawaii and Alaska), GSP growth per capita averaged over 1981-1990, GSP per capita averaged over 1977-1980 and the output/income ratio averaged over 1981-2000. The table reveals very large geographical differences in dividend and interest income, with the Northeastern states displaying much higher levels than Southern states.

Delaware is an extreme outlier. GSP 1977-1980 also shows high variation with Alaska having an extremely high value of about 63,000 dollars per capita. Next highest is Wyominganother oil state - at 43,000. These oil states also exhibit the highest output/income ratios. 
The lowest ratio is found for Florida, which reflects capital income received by retirees who are no longer in the work force.

Table 4 reports the mean, maximum, minimum, and standard errors (across the 50 states) of the output/income ratio and all the regressors. The output/income ratio has a mean of about 1 by construction and has a standard deviation of $0.12 .{ }^{28}$ This is a large amount of variation because a value of 1.12 means that 12 percent of value produced shows up as income in other states on net. GSP 1977-1980 also shows large variation with the value of the output of the most productive state being more than 3 times that of the least productive state. GSP growth from 1981 to 1990 has a standard deviation of 15 percent, which means that several states grew more than 1.5 percentage point per year faster than the average state during that decade. There are large differences in the change in number of retirees and, in particular, population growth across states.

\subsection{Results from Empirical Regressions}

\section{Change Regressions}

Table 5 explores whether the change in the output/income ratio is explained by per capita output growth and lagged output/income ratios and whether the estimated coefficients are similar to those obtained from regressions on the simulated data. ${ }^{29}$ The regressions are performed for 47 states because we do not have dividend and interest income for Alaska and Hawaii, and Delaware is very atypical. Alaska is also very atypical, with an extremely high share of GDP due to oil-extraction. 
The effect of (lagged) GSP growth from 1980 to 1990 is statistically significant and this variable alone explains 41 percent of the variation in the output/income ratio. In autarky, the output/income ratio would be constant and equal to 1.0 and no regressors would be significant. The significant positive coefficient to lagged GSP growth supports our interpretation that an increase in TFP brings about growth and capital inflows. The estimated coefficient of about 0.3 implies that a state which from 1980 to 1990 grew 10 percent faster than the average state (1 percent faster during the 1980 s at the annual rate) would have an output/income ratio that would be 0.03 higher in the 1990s than in the 1980s. ${ }^{30}$ While we are not able to run exactly the same regression as those Glick and Rogoff (1995) discussed earlier (due to the fact that we cannot calculate the Solow residual), our results nonetheless indicate that interstate capital movements are much better described by the frictionless model than international capital movements.

We can get a rough order of magnitude of the net capital income flows involved as follows: the average per capita output of a state over our sample is about 30,000 dollars. An increase in the output/income ratio of 0.03 corresponds to 900 dollars worth of capital income being paid by residents of the average state to other states, annually. If this increase is mainly caused by a change in net ownership rather than a surge in productivity, we can expand on the quantification. If the return to capital is (say) 10 percent, this would imply that capital in the order of 9,000 dollars per capita were financed on net by other states.

In the second column of Table 5, we add (lagged) output/income from 1981 to 1990. This renders the coefficient to growth smaller at 0.09 while the coefficient to lagged output/income 
takes a value of -0.42 , which implies a half-life for the reversion of the output/income ratio to unity of 15 years. These values are very close to those found by simulating the theoretical model and regressing on simulated data (see Table 1).

In the third column, we add the rate of population growth. The estimated coefficient to population growth is 0.08 with a $t$ statistic of 1.83 . This coefficient is identical to that of growth which is exactly the prediction of the model if migrants arrive with little assets. ${ }^{31}$

In the last column, we add the change in the number of retirees normalized by population. This estimated coefficient is negative, as predicted, although the point estimate is much larger than predicted. However, the coefficient is not precisely estimated and not significantly different from 0.

\section{Change Regressions-Panel Specification}

We show the results of panel regressions where the data has been averaged over fewer years - these regressions provide more degrees of freedom although we expect the model to be too simple to match, say, annual data. In Table 6, we show regressions where each period is an average over 10-year intervals, 7-year intervals, and 5-year intervals, respectively. Column (1) repeats the last column of Table 5 for easy reference.

Column (2) displays the results for 7-year intervals which doubles our number of data points. The estimated coefficient to lagged growth is larger and very close to the predicted size from the simulated data. In this larger sample, this coefficient is now strongly significant. The coefficient to the lagged ratio measures how much the output/income ratio would 
revert towards unity, ceteris paribus, during one time period. When the length of the time interval becomes shorter this coefficient should become smaller and this is what we find. The estimates imply similar half-lives as those for the first column for the speed of reversion of the output/income ratio to unity. The coefficient to population growth declines with the interval length which may be due to limited variation in population growth at shorter intervals. The estimated value in column (2) is still consistent with our model and statistically significant. The coefficient to changes in number of retirees declines but this coefficient is numerically larger than predicted and now clearly insignificant. For the 5-year intervals, reported in column (3), the coefficients to lagged output and the lagged output/income ratio are still of the correct size and significant while the population and retirees variables now are very far from being significant.

We verified that the panel regressions do not give meaningful results at higher frequencies. This is to be expected because we ignore business cycle variations and adjustment costs in our model. All in all, the results of the panel regressions are robust to the choice of period length — when it is 5 years or longer - and are consistent with our model.

\section{Level regressions}

The level regressions are presented in Table 7 . Column (5) displays the results for our main specification, but in order to evaluate the impact of individual regressors as well as robustness, we show in column (1) the regression of the output/income ratio on (a constant and) Log Average GSP 1977-1980 and add regressors one-by-one in the remaining columns 
in the order in which we found the regressors to be of interest a priori.

In column (1), Log Average GSP 1977-1980 is statistically significant at conventional levels. This variable explains 34 percent of the variation in the dependent variable according to the $R^{2}$ and the coefficient is positive. A positive sign is consistent with capital flowing to productive states with high output. The coefficient is about 0.3 , which implies that a state with output 10 percent above average has a ratio of output/income 3 percent above average. Since the output/income ratio is 1 on average this implies that a state that produces 50 percent more than the U.S. average is predicted to have an output/income ratio of about 1.15, which means that approximately 15 percent of the state's output accrues to income in other states. Thus, the estimated coefficient is economically large and meaningful. Compared to the estimate from simulated data the coefficient to GSP 1977-1980 is significantly larger; however the result matches the qualitative finding of our simulations that capital tends to flow to high output states.

Dividend and interest income, added in column (2), predicts the current output/income ratio negatively, as predicted, with a very high $t$-statistic even though the historical variable refers to observations more than 50 years ago. The estimated coefficient implies that states with a 10 percent higher than average level of interest and dividend income in the 1940s has an output/income ratio that is almost 1 percent lower today. If states with relatively high income in the past invested their savings in states with high total factor productivity, this is what we would expect to find. One might find it surprising that the effect is as long lasting as this result indicates but in our regression using simulated date we also found 
ownership shares 50 years in the past to be highly significant. (We can't compare the actual coefficients because the historical dividend and interest income data doesn't correspond exactly to ownership shares.)

The coefficient to oil share, in column (3), is likewise highly statistically significant. The inclusion of this variable lowers the coefficient to GSP 1977-1980 somewhat relative to column (2), but this is exactly what our model would lead us to believe: an oil price shock is a direct measure of productivity of capital in the "oil states." The impact of oil, as measured from the regression, is large - the coefficient of about 0.56 implies that a state, such as Wyoming, with a fraction of oil in GDP of 0.25 , has an output/income ratio of 1.14, ceteris paribus, implying that 14 percent of output shows up as income in other states due to the effect of this variable alone. Wyoming's output is on the order of 40,000 dollars per capita, and 14 percent of that is about 6,000 dollars, which - if we assumed a rate of return of 10 percent, would imply that capital in the oil-extraction sector in the amount of 60,000 dollars per capita is owned by out of state residents. While this number is based on several imputations and not likely to be exact, it highlights that on average the amount of out-ofstate capital invested in oil-extraction (capital that is installed in Wyoming but owned by other states) is very large.

Adding percent retirees, in column (4), we find a negative significant coefficient in line with our model. This supports the notion that retirees receive income from savings but contribute little to output. This coefficient is also large in economic terms. A state like Florida has almost 50 percent more retirees than average and our results predict that Florida 
has an output/income ratio 5 percent below average because of the large number of retirees in the state.

\subsection{Robustness: Measures of Income and Further Controls}

\section{Measuring income}

The validity of our interpretations is highly dependent on the difference between output and our income variable being a reasonable approximation to net capital income from other states, so we find it important to demonstrate that our main results are robust to reasonable alternative ways of calculating our income variable.

A simple modification of SPI that may make the data correspond better to GNI is to use SPI minus federal transfers, rather than simply SPI. The transfers included in SPI involve redistribution (typically) from richer to poorer individuals and, in particular, redistribution from younger to older individuals. A second modification, which is the closest approximation to "state-level GNI," is to calculate "state income," which is the income that would have been available for consumption by the residents of the state had there been no fiscal intervention on the part of the federal government following the methodology of Asdrubali, Sørensen, and Yosha (1996). We approximate GNI as "state income" plus retained corporate earnings. Retained corporate earnings are not available by state and we impute the state-level numbers from aggregate data. ${ }^{32}$ One last modification, that will make the difference between SPI and GSP correspond more closely to the capital income component of factor income flows (while making it less similar to GNI) is to subtract from the SPI of state $i$ the (net) income that 
commuters living in state $i$ earn in other states, since commuter's income is equivalent to the foreign earnings of country's residents. We are able to do so using the "adjustment for residence" data from the BEA. This adjustment is equal to the wage income earned by residents of state $i$ that work in other states (not $i$ ) minus the wage income earned by residents of other states (not $i$ ) that work in state $i$. Thus, it is the wage component of a state's "foreign" (from other states) net factor income. ${ }^{33}$

In Table 8, we explore whether the level regressions are sensitive to the precise definition of "income" in the denominator of the output/income ratio. Overall, the estimates are quite robustly estimated, with the signs and relative magnitudes showing little variation across the columns. Column (1) replicates the fourth column of Table 7 . In column (2), personal income is adjusted for federal transfers. In this column, the estimated impact of retirees in the population becomes statistically insignificant which indicates that a large part of the income of retirees consists of federal transfers (notably social security and medicare). In column (3), we adjust personal income for cross-state commuters' wage income. This adjustment lowers the coefficients to dividend and interest income and GSP 1977-1980, although these regressors are still statistically significant. One might argue that this choice of income data fits the model more directly and the lower coefficient estimated for this choice is actually closer to that found using simulated data. In column (4), approximate GNI is used rather than personal income but the estimated coefficients are quite similar to those of column (1) except that the fraction of retirees is not statistically significant-likely because federal transfers are not part of approximate GNI. Overall, our results are robust to these 
different definitions of income with some adjustments actually making the results closer to the simulation benchmark. The change regressions give results that are even more robust to the definition of income and we do not display the results here. ${ }^{34}$

\section{Additional Controls}

For further robustness check, we consider the following variables whose inclusion in the regressions do not change the results and for which details are therefore not tabulated.

Geography: Historically, the northern states were the seat of U.S. industrialization and much wealthier than the south. Anecdotal evidence suggests that capital has moved to the U.S. South as labor productivity was catching up with the North due to improved education as described by, e.g., Connolly (2003) and Caselli and Coleman (2001). We define a dummy variable, which takes the value 1 for New England, Mid-East, and Great Lakes and 0 for other regions. ${ }^{35}$

Sectoral shares other than oil: Historically, agricultural areas have often been laggards in terms of TFP growth, but this may not be true in recent periods for the United States. We include the share of agriculture in GSP in the same way as oil and mineral extraction. We further include the share of manufacturing in GSP.

Human capital: Residents in states with a relatively high number of educated individuals may have higher output relative to their income if individuals with college degrees (partially) financed their student loans from savings in other states or human capital may be correlated with TFP. We use human capital measured as the number of college graduates in a state 
relative to population in 1989 (the first available year for this variable). ${ }^{36}$

\section{Conclusion}

In spite of the surge in international capital flows in the last decade their magnitude is still below what typical models predict and they go in the "wrong" direction. Recent theoretical work attempting to better match the real world data has shifted the attention to portfolio models of the current account.

We adopt a different approach. We develop a simple (constant savings rate) dynamic general equilibrium model with persistent productivity shocks and full diversification of capital income. In this model, relative investment is determined by relative productivity, independently of relative savings. Our model predicts - as the new portfolio models - that net foreign ownership positions are mean-reverting. Essential for our result is the assumption that capital is fully diversified such that net flows are not primarily determined by risk considerations.

An advantage of our framework is that it is easily related to the data. We test the model using data from the U.S. states. The model predicts that capital flows to fast growing states from slow growing states and as a result high growth states pay capital income to other states. With persistent productivity shocks high output_ "rich" — states end up being net debtors.

At the country level, foreign asset and liability positions in the OECD has increased at a remarkable rate in the 1990s. Nonetheless, almost all countries hold amounts of foreign 
assets below the level of GDP (with Ireland being a notable exception). ${ }^{37}$ Why foreign asset holdings are "too low" is one of the biggest puzzles in international finance. Our evidence suggests that capital flows and ownership patterns across U.S. states are consistent with a simple frictionless neoclassical model. Therefore, the small size and "wrong" direction of net international capital flows is likely due to frictions associated with national borders. 


\section{Acknowledgements}

An earlier version of this paper is circulated under the title "Net Capital Flows and Productivity: Evidence from U.S. States." For help with the data, we thank Jeffrey Newman, Gerard Aman, and especially Kathy Albetski from the BEA, and Edward Trevelyan from the Federal Programs Branch, Governments Division, at the U.S. Census Bureau. For helpful comments, we thank participants of the seminars at Bocconi University, University of British Columbia, University of California at Davis, University of Copenhagen, Indiana University, University of Missouri, New York University, the Central Bank of Norway, University of North Carolina, North Carolina State University, University of Oregon, University of Pennsylvania, Rice University, Stanford University, and Trinity College. We also thank participants at the CEPR conference on Macroeconomics and Economic Geography in Modena 2003, the CEPR conference on Understanding Productivity Differences across Sectors, Firms and Countries in Sardegna 2004, the Globalization and Real Convergence Workshop at the CEU in Budapest, the 2004 LACEA meetings in Costa Rica, the 2004 Midwest Economics Meetings in St. Louis, the 2005 AEA meetings in Philadelphia, the 2005 NBER Universities Research Conference, the 2006 IEFS meetings in Boston, the 2006 DG ECFIN Annual Research Conference, the 2007 SED meetings in Prague, and the Oved Yosha memorial conference in Tel Aviv for their suggestions. In particular, we thank Marcelo Bianconi, Laura Bottazzi, Francesco Caselli, John Coleman, Oliver Dieckmann, Jonathan Eaton, Boyan Jovanovic, Peter Klenow, Narayana Kocherlakota, Miklos Koren, Philip Lane, John Lapp, Robert Lucas, Gian Maria Milesi-Ferretti, Kevin O'Rourke, David Papell, and 
Julio Rotemberg. Oved Yosha died from cancer on August 7th, 2003. His much too early death leaves a void in our hearts and in our profession. 


\section{Notes}

1Obstfeld and Taylor (2005) characterize 1990s as the era of limited "development finance" relative to "diversification finance."

${ }^{2}$ As stressed by Lucas (1990), capital should flow from rich to poor countries according the Solow model when capital markets are integrated and the level of total factor productivity is constant across countries and over time.

${ }^{3}$ The literature provides evidence that labor mobility is not so fast as to instantly equalize wages across states. Bernard et al. (2005) show that there are significant skilled-wage differences across states which implies low levels of net migration. Bound and Holzer (2000) find that imperfect mobility of unskilled workers in the United States contributed to increased income inequality in the 1980 s.

${ }^{4}$ More precisely, capital pays capital income in the form of dividends, interest, and rents to individuals in other states and across and within multi-state companies. Capital income flows to and from other states also provide risk sharing and our results complement studies such as Asdrubali, Sørensen, and Yosha (1996): they find that state-level income is about 40 percent insured against output shocks.

${ }^{5}$ Examples of frictions associated with borders are explicit barriers to investment or factors affecting investors ex post returns such as bad institutions (corruption and rule of law), and sovereign risk; see, for example Alfaro, Kalemli-Ozcan, and Volosovych (2008) and Reinhart and Rogoff (2004).

${ }^{6}$ The difference between Gross Domestic Product and Gross National Income is net factor 
income which includes net earnings of domestic residents abroad (not based on citizenship). However, foreign earnings of domestic residents are usually fairly small compared to capital income.

${ }^{7}$ At the country level capital flows are usually directly observed, but Bertocchi and Canova (2002) use the output/income ratio to infer past net inflows of capital to former African colonies where the historical capital flows data of interest are not observed.

${ }^{8}$ According to Kraay and Ventura (2000) capital flows are caused by portfolio growth through changes in wealth. In their model countries invest the marginal unit of wealth as the average unit such that portfolio shares are constant. More recent papers, such as Devereux and Sutherland (2006) and Tille and van Wincoop (2008), focus on general equilibrium effects and show that international capital flows can be broken down into a portfolio growth component, associated with savings, and a portfolio reallocation component, associated with changes in expected risk and returns.

${ }^{9}$ The assumption that the United States is a closed economy is not likely to affect our empirical results since our regressions control for aggregate U.S.-wide effects.

${ }^{10}$ Each shareholder will own $\phi_{i t} K_{t} / S_{i t}$ shares.

${ }^{11}$ Gruber (2000) even finds no responsiveness of the current account to real growth rates for a panel of OECD countries during 1975-2000.

${ }^{12}$ More precisely, "permanent" shocks refer to the case where income is well described by a time series model with a unit root where permanent income rises at least as much as current income. The simplest case is that of a random walk where shocks to current income equals 
shocks to permanent income. Since a random walk model for (OECD) country-specific shocks cannot be statistically rejected the finding of larger responses of investments than current accounts constitutes a puzzle. However, time series tests can not separate random walks from mean reverting $\mathrm{AR}(1)$ processes with a coefficient to lagged productivity very close to unity. If income is mean reverting savings will increase following a positive shock.

${ }^{13}$ Kraay and Ventura (2000) develop a model where investment risk is high and diminishing returns are weak. Their model implies that positive productivity shocks lead to deficits in debtor countries and surpluses in creditor countries. In our model, because of full diversification and no risk premia, relative investment will be determined by relative productivity with no role for savings. Hence, both debtor and creditor countries can attract capital on net if they hit by positive productivity shocks.

${ }^{14}$ Note that Gourinchas and Jeanne (2007) and Prasad et al. (2007) find exactly the opposite in a developing country context; i.e., they find a positive correlation between current account and growth and that capital goes to less productive countries.

${ }^{15}$ For example, including taxes, insurance, cost of heating/cooling, transportation, endowments of oil or minerals, agglomeration benefits etc. to the extent that these impact on the marginal return to capital investment.

${ }^{16}$ We checked empirically that for OECD countries the level of TFP (identified as the Solow-residual) is positively correlated with the level of capital (both averaged over 19702000) and that the change in TFP and the change in capital from 1970-1975 to 1976-2000 also are positively correlated. The correlations are 0.21 and 0.37 , respectively. 
${ }^{17}$ More precisely we average over periods 39-49 where the left-hand side is averaged over periods $81-100$.

${ }^{18} \mathrm{~A}$ quantity index for real GDP-growth is available for states but our specification captures the effect of, for example oil-price variation on capital flows, which we would substantially miss if we used quantity indices.

${ }^{19}$ We don't display further details, but a closer study reveals this pattern to mainly be driven by Michigan, likely due to the car industry in Detroit attracting significantly less capital after 1970 than it did earlier.

${ }^{20}$ It would be a major challenge to construct state-level current accounts today. Romans picked the two cycle-peak years of 1953 and 1957. His total investment estimates for each state are calculated by aggregating investment in manufacturing, mining, railroads, other transportation, public utilities, communications, agriculture, and construction. He uses annual surveys for some industries and balance sheets of companies (railways, utilities, etc.) for others. For industries where neither is available, he imputes from aggregate investment figures utilizing state-level wages and salaries for that particular industry. His saving estimates are based on state-level data, when available, on currency and bank deposits, saving and loan shares, private insurance and pension reserves, consumer debt, securities loans, mortgages, and bank debt, and involves a large number of imputations.

${ }^{21}$ We leave out Alaska, Hawaii and Delaware, in order to be consistent with the level regressions.

${ }^{22}$ We avoid using overlapping samples for the regressor (output) and the dependent variable 
(the output/income ratio) for the simple reason that output is used in the numerator of this ratio and measurement error would lead to a spurious positive correlation of output with the output/income ratio.

${ }^{23}$ Equation (5) contains the term $-\alpha d S / L$ or $\Delta S / L$ in discrete time. If $\Delta S=\Delta$ Retirees $+\Delta$ Other Asset Holders, the coefficient to $\Delta$ Retirees $/ L$ is expected to be $-\alpha$, even if the contribution from unobserved Other Asset Holders/ $L$ goes into the error term.

${ }^{24}$ The correlation between population growth and migration across states in the 1990s is 0.96 .

${ }^{25}$ For example, if each retiree holds 50 percent of the assets of an average stock holder the effective change in $S$ due to retirees would be only 0.5 times the change in number of retirees. The impact on the output/income ratio according to the model would then be $-0.5 \alpha$.

${ }^{26}$ The historical dividend and interest income data was made available to us by the BEA. The BEA publishes the sum of dividend, interest, and rent income, together with other income data, going back to 1929. We prefer to use data that does not include rental income, because this type of income is mostly imputed rental income of locally used and owned property.

${ }^{27}$ Alaska is not included in the regressions. Including Alaska would make the results more significant.

${ }^{28}$ The mean is not exactly equal to 1 due to normalization by the aggregate rather than the average U.S-wide values.

${ }^{29}$ We include a constant in the regression so the estimated effect of, say, output growth can 
be interpreted in line with the model prediction for a change in output keeping the aggregate constant.

${ }^{30}$ For example, North Carolina's per capita GDP grew 13 percent faster than average GDP over the 1980s.

${ }^{31}$ We attempted to also include as a regressor the rate of net inter-state migration as a percent of state population 1975-1980 in order to directly examine the issue of migration. The migration variable is, however, so closely correlated with population growth that we obtained non-sensible results due to multi-collinearity. Substituting the population growth rate with net inter-state migration gives very similar results.

${ }^{32}$ See the data appendix for details.

${ }^{33} \mathrm{~A}$ different approach is to use direct estimates of net external assets for U.S. states 19712001 imputed by Duczynski (2000). These estimates are based on personal dividend, interest, and rental income. Personal dividend income constitutes only about 5 percent of total personal income - a fraction much lower than the share $\alpha$ (typically 0.33 ) of output accruing to capital. The resulting estimates of net capital income flows may well underestimate the extent of net capital income flows for some states because capital income flows between (or within) firms in different states may never enter personal property income. In spite of these differences, using Duczynski's data in regressions similar to the ones reported result in qualitatively similar results, although the exact coefficients estimated can not be comparedsee the working paper version of this paper (NBER WP \#11301) for details.

${ }^{34}$ The change regressions show almost no sensitivity to the definitions of income and we do 
not display the details here. The details are available in the working paper version (NBER WP \#11301) of this article.

${ }^{35}$ We constructed this dummy variable after experimenting with dummy variables for all regions in multivariate regressions including our other regressors. The estimated effects were consistent with these three regions being different from the remaining regions. This result, of course, corresponds to the fact that these are the three regions with low output/income ratios.

${ }^{36}$ All the robustness exercises are available from www.uh.edu/skalemli and on request.

${ }^{37}$ Typical neoclassical models imply that an average state should hold foreign capital in an amount of about 3 times GDP. 


\section{Appendix A: Relation between GDP and GNI of the United States.}

U.S. GDP (Gross value of production physically in the United States)

+ Income from U.S. owned direct investment in other countries

- Income of foreign owned direct investment in the United States

+ Income from U.S. owned portfolio investment in other countries

- Income of foreign owned portfolio investment in the United States

+ Income from U.S. government investment in other countries

- Income of foreign investment in United States government assets

+ Wage and salary earned in other countries by residents of the United States

- Wage and salary earned in the United States by residents of other countries

+ Taxes on production and imports (collected by the United States from foreign companies)

- Taxes on production and imports (collected by foreign governments from U.S. companies)

$=$ U.S. GNI (Gross value of production owned by U.S. residents)

+ Subsidies - Indirect business taxes (domestic)

- Corporate saving

- Net interest

+ Personal interest income

- Contributions for social insurance

+ Government transfers to persons

$=$ Personal Income 
Notes: (i) Residents of the United States contribute to U.S. GNI whether they are citizens of the Unites States or not and, while the number of foreign citizens in the United States is large, the total wage and salary of foreign residents in the United States is fairly small (less than 4 percent of total U.S. income payments to foreign countries in 2002).

(ii) Government investments abroad are mainly official currency reserves, while government liabilities are mainly treasury securities. For further details, see OECD (1993), "System of National Accounts Glossary 1993" and BEA (2003), "Preview of the 2003 Comprehensive Revision of the National Income and Product Account," Survey of Current Business, June 2003. 


\section{Data Appendix}

GSP: State-level GDP, denoted Gross State Product (GSP), is published by the Bureau of Economic Analysis (BEA). GSP is derived as the sum of value added originating in all industries in the state, thus it is exactly the state-level equivalent of GDP. See Beemiller and Downey (2001).

GSP is calculated from the income side of the accounts and contains three components: compensation of employees; taxes on production and imports (TOPI); and gross operating surplus (including noncorporate income). "Compensation of employees" consists mostly of employee wages and salaries disbursements; to keep consistency with the rest of the GSP components the BEA adjusts these disbursements to reflect production; i.e., when labor services were employed, rather than when they were actually paid. For most industries and GSP components, the estimates are based on establishment data (rather than company data) by state. Thus, GSP is calculated on a "when accrued, where accrued" basis.

GSP estimates are available for 1977-2000. GSP data exists for 1963-1976 as well, but is based on a different methodology which is inconsistent with the 1977-2000 estimates.

SPI: State-level Personal Income (SPI) is also published by the BEA. SPI is defined as the income received by, or on behalf of, all the residents of the state and is designed to be conceptually and statistically consistent with the U.S. national estimates of personal income.

The SPI estimates are primarily based on administrative-records data and on data from censuses and surveys. The data from administrative records (like Federally-administered transfer programs) may originate either from the recipients of the income or from the source 
of the income; for example, federal transfers may be reported by the federal government or by the recipient states or individuals. The data from censuses is mainly collected from the recipient of the income. Some data is reported and recorded by the recipient's place of work rather than by the recipient's place of residence. Therefore, adjustments are made to the data in order to reflect the recipient's place of residence. Most adjustments are directly applied to the series that the BEA publishes, but the largest adjustment, "Adjustment for residence" of earnings is reported separately.

SPI is derived as SPI=Earnings by place of work - Contributions for government social insurance (by employee and employer) + Adjustment for residence+ Dividends, interest, and rent+ Personal current transfer receipts.

Persons (from "personal income") consist of individuals, nonprofit institutions that serve individuals, private non-insured welfare funds, and private trust funds. The wage component of SPI takes into account cross-state commuters, so that the wages of persons residing in a particular state but working elsewhere (another state, Canada or Mexico), even temporarily, are included in that state's personal income; see "net commuters' income" description below. Other components of SPI, like estimates of non-farm proprietors' income and of contributions for government social insurance by the self-employed are derived from source data that is reported by the tax-filing address of the recipient. This address is usually that of the proprietor's residence; therefore, the data is, in principle, recorded by place of residence. Thus, SPI is defined on a "when earned, where earned" basis. SPI is available for our entire sample. 
The difference between SPI and GSP: Conceptually, the main difference between GSP and SPI is that while GSP is defined on a "when accrued, where accrued" basis, SPI is defined on a "when earned, where earned" basis. The methodology of estimating these series reflect the difference. This means that they are estimated using different data sources: GSP estimates are based on payrolls from establishment data, while SPI estimates are based on income from administrative-records and censuses. So although both are measured form the income side they are based on different data.

A few examples may clarify this difference. Suppose a machine produces widgets in Wisconsin. The output of that machine minus the cost of its inputs will be recorded as part of Wisconsin's GSP. But if the firm that operates the machine is partially owned by someone that lives in Ohio, where he or she reports dividend income for tax purposes, then this dividend income will show up in Ohio's SPI. Now suppose that the machine needs a worker to operate it. The workers wage is accrued to Wisconsin's GSP, but if he or she lives in Iowa, the salary will show up in Iowa's SPI.

Federal Transfers: This series is the sum of 11 different series, each of which we identify as measuring transfers from the U.S. federal government to individuals or state-specific institutions (typically governments). ${ }^{1}$

Net Commuters' Income: This series is denoted "Adjustment for Residence" by the BEA

\footnotetext{
${ }^{1}$ The series - published by the BEA and available for our entire sample - are: "Old age, survivors and disability insurance payments," "Railroad retirement and disability payments," "Workers' compensation payments (Federal and State)," "Medical payments," "Supplemental security income (SSI) payments," "Food stamps," "Other income maintenance," "Unemployment insurance benefit payments," "Veterans' benefits payments," "Federal education and training assistance payments (excl. veterans)," "Federal government payments to nonprofit institutions." The series for workers compensation includes some transfers which are not from the federal government but we did not attempt to correct for this.
} 
and is available for our entire sample. It is a component of SPI. The adjustment is equal to the wage income earned by residents of state $i$ that work in other states (not $i$ ) minus the wage income earned by residents of other states (not $i$ ) that work in state $i$. Thus, it is the wage component of a state's "foreign" (from other states) net factor income. The BEA estimates this series by using "Journey to Work" surveys, which are performed by the Census Bureau.

State Income: State income is calculated starting from the BEA data for SPI, which is pre-personal income tax but post- all other federal taxes as well as post- social security contributions and transfers. Therefore, we add to SPI personal and employer social security contributions and subtract social security transfers. We further add state non-personal taxes, in order to combine non-cancelling income of the state government and the residents of a state - the taxes collected by the government of the state are available for consumption by its residents, possibly in the form of public goods. Finally, we add the interest revenue on the state's trust funds. The detailed construction of State Income involves a large number of data sources and a number of imputations; see Asdrubali, Sørensen, and Yosha (1996) for details.

Corporate Retained Earnings: Corporate retained earnings of firms are reported by the BEA only at the aggregate U.S. level, and are available for our entire sample. We impute state corporate retained earnings by allocating the aggregate number to each state according to its share in aggregate personal dividend income.

Historical Dividend and Interest Income: Separate series of personal dividend income 
and personal interest income have been made available to us by Kathy Albetsky from the BEA for 1929-2000. The BEA publishes the sum of personal dividends, interest, and rent income by state in 1929-2000.

Population: This series is published by the BEA and is available for our entire sample.

Oil Prices: This series was obtained from the Energy Information Administration in the U.S. Department of Energy for 1968-2000.

Oil Share: The BEA publishes estimates of the value added in the "Oil and gas extraction" industry sector by state. "Oil Share" is the percent of this sector in GSP.

Retirement: The Census Bureau publishes age profiles of the population by state for 19702000 (unfortunately, we could not obtain the data for 1972). We use the number of people age 65 and above as our measure of retired persons.

SPI-transfers: SPI minus Federal Transfers.

SPI-commuters' income: SPI minus Commuters' Net Wage Income (Adjustment for Residence).

GNI (approximation): State Income from Asdrubali, Sørensen, and Yosha (1996) plus Corporate Retained Earnings. 


\section{References}

Alfaro, Laura, Sebnem Kalemli-Ozcan, and Vadym Volosovych, "Why Doesn't Capital Flow from Rich to Poor Countries? An Empirical Investigation," The Review of Economics and Statistics 90 (2008), 347-368.

Asdrubali, Pierfederico, Bent E. Sørensen, and Oved Yosha, "Channels of Interstate Risk Sharing: United States 1963-90," Quarterly Journal of Economics 111 (1996), 1081-1110.

Atkeson, Andrew and Tamim Bayoumi, "Private Capital Markets and Adjustment in a Currency Union: Evidence from the United States," in Paul R. Masson and Mark P. Taylor, eds., Policy Issues in the Operation of Currency Unions, New York: Cambridge University Press (1993a).

Atkeson, Andrew and Tamim Bayoumi, "Do Private Capital Markets Insure Regional Risk? Evidence from the United States and Europe," Open Economies Review 4 (1993b), $303-324$.

Beemiller, Richard M. and George K. Downey, "Gross State Product by Industry, 1992-99," Survey of Current Business 81 (August 2001), 159-172.

Bernard, Andrew, Stephen Redding, and Peter Schott, "Factor Price Equality and the Economies of the United States," CEPR Working Paper No. 5111, (2005).

Bertocchi, Graziella and Fabio Canova, "Did Colonization Matter for Growth? An Empirical Exploration into the Historical Causes of Africa's Underdevelopment," European Economic Review 46 (2002), 1851-1871. 
Blomstrom, Magnus, Robert E. Lipsey, and Mario Zejan, "Is Fixed Investment the Key to Economic Growth?" Quarterly Journal of Economics 111 (1996), 269-276.

Bound, John and Harry J. Holzer, "Demand Shifts, Population Adjustments, and Labor Market Outcomes during the 1980s," Journal of Labor Economics 18 (2000), 20-54.

Bureau of Economic Analysis, State Personal Income 1929-1997, U.S. Department of Commerce, Economics and Statistics Administration, (1999).

Caselli, Francesco and Wilbur John Coleman II, "The U.S. Structural Transformation and Regional Convergence: A Reinterpretation," Journal of Political Economy 109 (2001), $584-616$.

Connolly, Michelle P., "Human Capital and Growth in the Post-Bellum South: A Separate but Unequal Story," Duke University, (2003) mimeo.

Devereux, Michael, and Alan Sutherland, "Country Portfolio Dynamics," University of British Columbia, (2006) mimeo.

Duczynski, Petr, "Capital Mobility in Neoclassical Models of Growth: Comment," American Economic Review 90 (2000), 687-694.

Glick, Reuven and Kenneth Rogoff, "Global versus Country-Specific Productivity Shocks and the Current Account," Journal of Monetary Economics 35 (1995), 159-192.

Gourinchas, Pierre-Olivier and Olivier Jeanne, "Capital Flows to Developing Countries: The Allocation Puzzle," University of California, Berkeley, (2006) mimeo. 
Gruber, Joseph, "Increased Current Account Dispersion: Differential Growth, Demographic Dispersion, or Greater Financial Integration?" Board of Governors, Federal Reserve Bank, (2000) mimeo.

Kalemli-Ozcan, Sebnem, Belgi Turan, and Bent E. Sørensen, "Where Does Capital Flow? A Comparison of U.S. States and EU Countries 1950-2000," in Lars Jonung, Christoph Walkner, and Max Watson, eds. Building the Financial Foundations of the Euro. London: Routledge, (2008).

Kraay, Art and Jaume Ventura, "Current Accounts in Debtor and Creditor Countries." Quarterly Journal of Economics 115 (2000), 1137-1166.

Lucas, Robert, "Why doesn't Capital Flow from Rich to Poor Countries?" American Economic Review 80 (1990), 92-96.

North, Douglas, The Economic Growth of the United States 1790-1860, New York: W.W. Norton, (1961).

Obstfeld, Maurice and Alan M. Taylor, Global Capital Markets: Integration, Crisis, and Growth, New York: Cambridge University Press, (2005).

Prasad, Eswar S., Raghuram G. Rajan, and Arvid Subramanian, "Patterns of International Capital Flows and Their Implications for Economic Development," Proceedings of the 2006 Jackson Hole Symposium, (2007) 119-158.

Reinhart, Carmen M. and Kenneth Rogoff, "Serial Default and the 'Paradox' of Rich-to- 
Poor Capital Flows," American Economic Review: Papers and Proceedings 94 (2004), $53-58$.

Romans, John T., Capital Exports and Growth among U.S. Regions, Middletown: Wesleyan University Press, (1965).

Tille, Cedric and Eric van Wincoop, "International Capital Flows," CEPR Discussion Paper No. 6705, (2008). 


\section{Table 1: Change in Net Capital Income Flows: Simulated Data}

Dependent Var.: Avg. Out./Inc. T-9 to T minus Avg. Out./Inc. T-19 to T-10

\begin{tabular}{lcc}
\hline \hline & $(1)$ & $(2)$ \\
& & \\
Output Growth & 0.08 & 0.13 \\
T-19 to T-10 & $(0.04)$ & $(0.03)$ \\
& & -0.44 \\
Output/Income & - & $(0.10)$ \\
T-19 to T-10 & - & \\
\end{tabular}

Notes: The table reports the results of cross-sectional regressions for 50 "states" on simulated data. The specification parallels the regressions using actual data reported in Table 5, columns (1) and (2). A constant was included but is not reported. The coefficients are averages over 200 simulations and standard deviations across the 200 simulations are reported in parentheses. The simulated data are calibrated to match long-run trends in the aggregate U.S. economy and state-level output data. The data are simulated for $\mathrm{T}=100$ "years." The left hand side is the logarithm of the ratio of GDP to GNI averaged over years T-9 to T minus the ratio of GDP to GNI averaged over years T-19 to T-10. "Output Growth T-19 to T-10" is the logarithm of state GDP in year T-10 minus the logarithm of state GDP in year T-19. "Output/Income T-19 to T-10" is ratio of GDP to GNI averaged over the years $\mathrm{T}-19$ to $\mathrm{T}-10$. See the text for parameter values. 
Table 2: Net Capital Income Flows: Simulated Data

Dependent Variable: Log of Average Output/Income T-19 to T

\begin{tabular}{lcc}
\hline \hline & $(1)$ & $(2)$ \\
& & \\
Log Average Output & 0.05 & 0.09 \\
T-23 to T-19 & $(0.02)$ & $(0.04)$ \\
& & -0.14 \\
Ownership Share & - & $(0.04)$ \\
T-61 to T-51 & - & \\
\hline
\end{tabular}

Notes: The table reports the results of cross-sectional regressions for 50 "states" on simulated data. The specification parallels the regressions using actual data reported in Table 7, columns (1) and (2). A constant was included but not reported. The coefficients are averages over 200 simulations and standard deviations across the 200 simulations are reported in parentheses. The simulated data are calibrated to match long-run trends in the aggregate U.S. economy and state-level output data. The data are simulated for $\mathrm{T}=100$ "years." The left-hand side is the logarithm of the ratio of GDP to GNI averaged over years T-19 to T and "Log Average Output" is the logarithm of the level of GDP averaged over years T-23 to T-19. "Ownership Share T-61 to T-51" is the logarithm of the share of ownership of the aggregate capital stock averaged over years T-61 to T-51. See the text for parameter values. 
Table 3: Descriptive Statistics by State

\begin{tabular}{|c|c|c|c|c|c|}
\hline & $\begin{array}{l}\text { Avg. Dividend } \\
\text { Inc. } 1939-1949\end{array}$ & $\begin{array}{r}\text { Avg. Interest } \\
\text { Inc. } 1939-1949\end{array}$ & $\begin{array}{r}\text { GSP Growth } \\
1980-1990\end{array}$ & $\begin{array}{l}\text { Avg. GSP } \\
1977-1980\end{array}$ & $\begin{array}{r}\text { Avg. Out/Inc } \\
1981-2000\end{array}$ \\
\hline Alabama & 91.54 & 163.34 & 19.22 & 20,201 & 0.98 \\
\hline Alaska & & & -46.04 & 63,426 & 1.63 \\
\hline Arizona & 182.46 & 300.29 & 3.76 & 23,502 & 0.97 \\
\hline Arkansas & 64.18 & 137.50 & 17.72 & 19,450 & 0.97 \\
\hline California & 451.10 & 561.99 & 15.97 & 29,642 & 1.02 \\
\hline Colorado & 301.04 & 437.14 & 7.11 & 27,640 & 1.00 \\
\hline Connecticut & 881.53 & 778.44 & 34.43 & 27,657 & 0.96 \\
\hline Delaware & 1846.49 & 860.02 & 40.49 & 28,380 & 1.21 \\
\hline Florida & 404.19 & 405.22 & 16.96 & 21,852 & 0.88 \\
\hline Georgia & 173.98 & 189.98 & 26.46 & 22,624 & 1.07 \\
\hline Hawaii & & & 26.50 & 29,492 & 1.06 \\
\hline Idaho & 85.37 & 269.30 & 4.65 & 22,958 & 0.97 \\
\hline Illinois & 421.06 & 498.47 & 15.41 & 28,595 & 0.99 \\
\hline Indiana & 214.20 & 305.85 & 14.57 & 24,489 & 0.98 \\
\hline Iowa & 164.52 & 347.55 & 6.66 & 25,988 & 0.98 \\
\hline Kansas & 115.39 & 299.11 & 9.14 & 25,432 & 0.97 \\
\hline Kentucky & 163.19 & 191.12 & 13.99 & 22,493 & 1.03 \\
\hline Louisiana & 155.54 & 221.39 & -10.47 & 29,678 & 1.23 \\
\hline Maine & 394.94 & 516.45 & 24.53 & 19,435 & 0.93 \\
\hline Maryland & 472.86 & 568.16 & 26.80 & 24,143 & 0.88 \\
\hline Massachusetts & 629.07 & 675.06 & 31.38 & 25,099 & 0.99 \\
\hline Michigan & 307.69 & 410.73 & 11.75 & 26,361 & 0.95 \\
\hline Minnesota & 248.94 & 380.58 & 15.16 & 26,416 & 0.99 \\
\hline Mississippi & 58.18 & 121.50 & 12.04 & 18,594 & 1.00 \\
\hline Missouri & 321.69 & 379.03 & 16.96 & 24,479 & 0.99 \\
\hline Montana & 197.74 & 342.49 & -8.18 & 24,322 & 0.94 \\
\hline Nebraska & 171.21 & 337.71 & 16.69 & 25,194 & 1.01 \\
\hline
\end{tabular}


Descriptive Statistics by State-continued

\begin{tabular}{lrrrrr}
\hline \hline & $\begin{array}{r}\text { Avg. Dividend } \\
\text { Inc. 1939-1949 }\end{array}$ & $\begin{array}{r}\text { Avg. Interest } \\
\text { Inc. 1939-1949 }\end{array}$ & $\begin{array}{r}\text { GSP Growth } \\
1980-1990\end{array}$ & $\begin{array}{r}\text { Avg. GSP } \\
1977-1980\end{array}$ & $\begin{array}{r}\text { Avg. Out/Inc } \\
1981-2000\end{array}$ \\
\hline Nevada & 534.41 & 549.99 & 5.48 & 32,226 & 1.07 \\
New Hampshire & 437.30 & 533.42 & 28.75 & 21,558 & 0.93 \\
New Jersey & 466.87 & 600.63 & 34.77 & 26,183 & 0.95 \\
New Mexico & 179.61 & 225.41 & -2.99 & 25,088 & 1.13 \\
New York & 726.88 & 908.47 & 23.34 & 28,652 & 1.02 \\
North Carolina & 153.86 & 152.73 & 26.11 & 22,269 & 1.05 \\
North Dakota & 72.11 & 252.14 & -5.13 & 25,003 & 1.01 \\
Ohio & 374.76 & 398.71 & 12.95 & 25,670 & 0.98 \\
Oklahoma & 150.98 & 223.83 & -8.52 & 24,848 & 0.99 \\
Oregon & 214.83 & 432.19 & 7.31 & 26,098 & 0.97 \\
Pennsylvania & 423.30 & 477.04 & 17.89 & 24,161 & 0.92 \\
Rhode Island & 583.55 & 598.69 & 23.96 & 21,802 & 0.92 \\
South Carolina & 90.14 & 155.05 & 26.03 & 19,560 & 1.00 \\
South Dakota & 105.65 & 239.10 & 21.06 & 21,935 & 1.01 \\
Tennessee & 137.32 & 189.95 & 23.17 & 21,786 & 1.02 \\
Texas & 171.05 & 265.15 & -3.12 & 29,488 & 1.12 \\
Utah & 175.30 & 287.17 & 8.38 & 22,802 & 1.04 \\
Vermont & 328.35 & 473.06 & 26.39 & 20,370 & 0.96 \\
Virginia & 230.20 & 235.47 & 27.16 & 24,191 & 0.99 \\
Washington & 232.67 & 431.22 & 16.38 & 27,577 & 0.99 \\
West Virginia & 173.37 & 186.22 & 0.95 & 21,599 & 0.94 \\
Wisconsin & 269.22 & 438.38 & 12.12 & 25,166 & 0.97 \\
Wyoming & 226.85 & 400.49 & -24.22 & 43,191 & 1.37 \\
\hline
\end{tabular}

Notes: Avg. Dividend Inc. 1939-1949 and Avg. Interest Inc. 1939-1949 are, respectively, dividend and interest income per capita in 2000 prices, averaged over 1939-1949. GSP growth 1980-1990 is the growth rate of GSP per capita, from 1980 to 1990. Avg. GSP 1977-1980 is GSP per capita in 2000 prices, averaged over 1977-1980. Average Out/Inc 1981-2000 is output divided by income (and normalized by U.S. output/income), where output is Gross State Product (GSP) and income is State Personal Income (SPI), averaged over 1981-2000. 
Table 4: Descriptive Statistics

\begin{tabular}{lrrrr}
\hline \hline & & & & \\
& Mean & S.D. & Max. & Min. \\
& & & & \\
\hline & & & & \\
Avg. Output/Income 1981-2000 & 1.02 & 0.12 & 1.63 & 0.88 \\
Avg. GSP 1977-1980 (\$1,000 per capita) & 25.8 & 6.80 & 63.4 & 18.6 \\
Avg. Div\&Int Inc. 1939-1949 (\$1,000 per capita) & 0.69 & 0.46 & 2.70 & 0.18 \\
Avg. Oil Share 1977-1980 (percent) & 3.00 & 6.00 & 22.00 & 0.00 \\
Retirees/Population 1980 (percent) & 11.00 & 2.00 & 18.00 & 3.00 \\
Avg. Out/Inc 1991-2000 minus Avg. Out/Inc 1981-1990 & -0.01 & 0.11 & 0.16 & -0.61 \\
GSP Growth from 1980 to 1990 (percent) & 13.68 & 17.56 & 37.27 & -49.94 \\
Population Growth from 1980 to 1990 (percent) & 7.43 & 9.09 & 36.47 & -8.63 \\
Change in Retirees/Population (percent) & 2.40 & 1.14 & 6.23 & 1.08 \\
Avg. Output/Income 1981-1990 & 1.03 & 0.17 & 1.93 & 0.87 \\
\hline
\end{tabular}

Notes: 47 observations (missing data for Alaska and Hawaii; the outlier Delaware is left out). Average Output/Income 1981-2000 is output divided by income (and normalized by U.S. output/income), where output is Gross State Product (GSP) and income is State Personal Income (SPI), averaged over 1981-2000. Average GSP 1977-1980 is GSP per capita in 2000 prices, averaged over 1977-1980. Average Div\&Int Inc. 1939-1949 is the sum of dividend and interest income per capita in 2000 prices, averaged over 1939-1949. Average Oil Share 1977-1980 is the share of the oil and mineral extraction sectors in GSP by state, averaged over 1977-1980. Retirees/Population 1980 is the share of retirees in state population in 1980. Avg. Out/Inc 1991-2000 minus Avg. Out/Inc 1981-1990 is the average of the ratio over 1991-2000 minus the average of the ratio over 1981-1990. GSP Growth is the rate of GSP per capita growth from 1980 to 1990. Population Growth is the rate of growth of state population from 1980 to 1990. Change in Retirees/Population is the change in the number of retirees from 1980 to 1990 divided by average population over 1980-1990. Average Output/Income 1981-1990 is output divided by income (and normalized by U.S. output/income), where output is Gross State Product (GSP) and income is State Personal Income (SPI), averaged over 1981-1990. 


\section{Table 5: Change in Net Capital Income Flows}

Dep. Var: Avg. Out/Inc 1991-2000 minus Avg. Out/Inc 1981-1990

\begin{tabular}{|c|c|c|c|c|}
\hline & (1) & $(2)$ & (3) & $(4)$ \\
\hline States & 47 & 47 & 47 & 47 \\
\hline $\begin{array}{l}\text { GSP Growth } \\
\text { from } 1980 \text { to } 1990\end{array}$ & $\begin{array}{l}0.30 \\
(3.12)\end{array}$ & $\begin{array}{l}0.09 \\
(1.81)\end{array}$ & $\begin{array}{l}0.08 \\
(1.75)\end{array}$ & $\begin{array}{l}0.06 \\
(1.29)\end{array}$ \\
\hline $\begin{array}{l}\text { Output/Income } \\
1981-1990\end{array}$ & - & $\begin{array}{l}-0.42 \\
(6.87)\end{array}$ & $\begin{array}{l}-0.42 \\
(7.59)\end{array}$ & $\begin{array}{l}-0.43 \\
(8.95)\end{array}$ \\
\hline $\begin{array}{l}\text { Population Growth } \\
\text { from } 1980 \text { to } 1990\end{array}$ & - & $\begin{array}{l}- \\
-\end{array}$ & $\begin{array}{l}0.08 \\
(1.83)\end{array}$ & $\begin{array}{l}0.17 \\
(2.71)\end{array}$ \\
\hline $\begin{array}{l}\text { Change in Retirees/Population } \\
\text { from } 1980 \text { to } 1990\end{array}$ & - & - & - & $\begin{array}{l}-0.92 \\
(1.39)\end{array}$ \\
\hline$R^{2}$ & 0.41 & 0.76 & 0.78 & 0.78 \\
\hline
\end{tabular}

Notes: 47 observations (missing data for Alaska and Hawaii; the outlier Delaware is left out). Avg. Out/Inc 1991-2000 minus Avg. Out/Inc 1981-1990 is the average of the ratio over 1991-2000 minus the average of the ratio in 1981-1990. Output/Income 1981-1990 is the average of the ratio over 1981-1990. GSP Growth is the rate of growth of GSP per capita from 1980 to 1990. Population Growth is the rate of growth of state population from 1980 to 1990. Change in Retirees/Population is the change in the number of retirees from 1980 to 1990 divided by average population over 1980-1990. A constant is included in all specifications. Heteroskedasticity robust $t$-statistics in parentheses. 


\title{
Table 6: Change in Net Capital Income Flows: Panel Regressions
}

\author{
Dep. Var: Change in Output/Income
}

\begin{tabular}{lccc}
\hline \hline & $(1)$ & $(2)$ & $(3)$ \\
& & & \\
Sample & $1981-2000$ & $1980-2000$ & $1981-2000$ \\
& & & \\
GSP Growth & 0.06 & 0.15 & 0.10 \\
Lagged & $(1.29)$ & $(3.87)$ & $(2.12)$ \\
& & & \\
Output/Income & -0.43 & -0.35 & -0.32 \\
Lagged & $(8.95)$ & $(12.33)$ & $(9.25)$ \\
& & & \\
Population Growth & 0.17 & 0.10 & 0.02 \\
Lagged & $(2.71)$ & $(2.11)$ & $(0.32)$ \\
& & & \\
Change in Retirees/ & -0.92 & -0.54 & 0.06 \\
Population, Lagged & $(1.39)$ & $(1.07)$ & $(0.10)$ \\
& & & \\
Interval length & 10 & 7 & 5 \\
Time Periods & 1 & 2 & 3 \\
Observations & 47 & 94 & 141 \\
& & & \\
$R^{2}$ & 0.78 & 0.73 & 0.60 \\
& & & \\
\hline
\end{tabular}

Notes: 47 states used in all regressions (missing data for Alaska and Hawaii and the outlier Delaware is left out). In each column the definition of a period of the panel changes; it is an average over a time interval, denoted "Interval length." For example, in column (2) the timeinterval in each period of the panel is 7 years; hence we have 2 periods covering 1987-2000 and a lagged period 1980-1986. The number of observations is $2^{*} 47=94$. Change in Output/Income is the difference between the output/income ratio in the current period and the previous one. GSP Growth Lagged is the total growth of GSP per capita within the previous period; thus, in column (2) it is the total growth over 7 years. Output/Income Lagged is the value the output/income ratio in the previous period. Population Growth Lagged is the total growth of population in the previous period. Change in Retirees/Population is the change in the number of retirees divided by average population in the previous period. A constant is included in all specifications. Heteroskedasticity robust $t$-statistics in parentheses. 
Table 7: Net Capital Income Flows

Dependent Variable: Log of Average Output/Income 1981-2000

\begin{tabular}{lcccc}
\hline \hline & $(1)$ & $(2)$ & $(3)$ & $(4)$ \\
& 47 & 47 & 47 & 47 \\
States & & & & \\
& 0.29 & 0.43 & 0.29 & 0.24 \\
Log Average GSP & $(3.12)$ & $(5.93)$ & $(4.95)$ & $(4.41)$ \\
1977-1980 & & & & \\
& - & -0.09 & -0.06 & -0.05 \\
Log Average Div\&Int & - & $(5.71)$ & $(3.97)$ & $(3.35)$ \\
Income 1939-1949 & - & - & 0.56 & 0.54 \\
& - & - & $(3.14)$ & $(3.47)$ \\
Log Average Oil Share & - & - & - & -0.11 \\
1977-1980 & - & - & - & $(2.72)$ \\
Log Retirees/Population & - & & & \\
1980 & 0.34 & 0.65 & 0.73 & 0.76 \\
$R^{2}$ & & & & \\
\hline
\end{tabular}

Notes: 47 observations (missing data for Alaska and Hawaii; the outlier Delaware is left out). Average Output/Income 1981-2000 is output divided by income (and normalized by U.S. output/income), where output is Gross State Product (GSP) and income is State Personal Income (SPI), averaged over 1981-2000. Average GSP 1977-1980 is GSP per capita in 2000 prices, averaged over 1977-1980. Average Div\&Int Income 1939-1949 is the sum of dividend and interest income per capita in 2000 prices, averaged over 1939-1949. Average Oil Share 1977-1980 is the share of the oil and mineral extraction sectors in GSP by state, averaged over 1977-1980; this regressor is transformed to $\log (1+$ share $)$ in order to dampen outliers and avoid zero observations. Retirees/Population 1980 is the share of retirees in state population in 1980. A constant is included in all specifications. Heteroskedasticity robust $t$-statistics in parentheses. 


\section{Table 8: Net Capital Income Flows: Other Measures of Income}

Dependent Variable: Log of Average Output/Income 1981-2000

\begin{tabular}{|c|c|c|c|c|}
\hline & (1) & $(2)$ & (3) & $(4)$ \\
\hline Dependent Var. & $\frac{\text { Out }}{\text { Inc.I }}$ & $\frac{\text { Out }}{\text { Inc.II }}$ & $\frac{\text { Out }}{\text { Inc.III }}$ & $\frac{\text { Out }}{I n c . I V}$ \\
\hline Income measure & SPI & SPI-Fed.Tr. & SPI-Commut. & Approx. GNI \\
\hline States & 47 & 47 & 47 & 47 \\
\hline $\begin{array}{l}\text { Log Average GSP } \\
\text { 1977-1980 }\end{array}$ & $\begin{array}{c}0.24 \\
(4.41)\end{array}$ & $\begin{array}{c}0.20 \\
(3.20)\end{array}$ & $\begin{array}{c}0.13 \\
(2.76)\end{array}$ & $\begin{array}{c}0.15 \\
(3.20)\end{array}$ \\
\hline $\begin{array}{l}\text { Log Average Div\&Int } \\
\text { Income 1939-1949 }\end{array}$ & $\begin{array}{l}-0.05 \\
(3.35)\end{array}$ & $\begin{array}{l}-0.06 \\
(3.97)\end{array}$ & $\begin{array}{l}-0.02 \\
(2.13)\end{array}$ & $\begin{array}{l}-0.06 \\
(4.23)\end{array}$ \\
\hline $\begin{array}{l}\text { Log Average Oil Share } \\
\text { 1977-1980 }\end{array}$ & $\begin{array}{c}0.54 \\
(3.47)\end{array}$ & $\begin{array}{c}0.65 \\
(3.53)\end{array}$ & $\begin{array}{c}0.62 \\
(4.43)\end{array}$ & $\begin{array}{c}0.52 \\
(2.97)\end{array}$ \\
\hline $\begin{array}{l}\text { Log Retirees/Population } \\
1980\end{array}$ & $\begin{array}{l}-0.11 \\
(2.72)\end{array}$ & $\begin{array}{l}-0.04 \\
(0.79)\end{array}$ & $\begin{array}{l}-0.17 \\
(5.44)\end{array}$ & $\begin{array}{l}-0.06 \\
(1.47)\end{array}$ \\
\hline$R^{2}$ & 0.76 & 0.72 & 0.78 & 0.69 \\
\hline
\end{tabular}

Notes: 47 observations (missing data for Alaska and Hawaii; the outlier Delaware is left out). Average Output/Income 1981-2000 is output divided by income (and normalized by U.S. output/income), averaged over 1981-2000, where output is Gross State Product (GSP) and our income measure varies as follows. Column (1) uses SPI for income. Column (2) uses SPI-Federal Transfers for Income. Column (3) uses SPI-Adjustment for Residence for Income. The adjustment for residence is equal to the wage income earned by residents of state $i$ that work in other states (not $i$ ) minus the wage income earned by residents of other states (not $i$ ) that work in state $i$. The mean of this variable as a percent of SPI for the sample here (47 states) is 0.7 percent; the standard deviation is 3 percent; the maximum (Maryland) is 11.4 percent; the minimum (New York) is -3.8 percent. Column (4) uses an approximation to state-level GNI based on Asdrubali et al. (1996) (see data appendix for details). This variable is available till 1999 so all the variables in this column are re-defined accordingly. Average GSP 1977-1980 is GSP per capita in 2000 prices, averaged over 1977-1980. Average Div\&Int Income 1939-1949 is the sum of dividend and interest income per capita in 2000 prices, averaged over 1939-1949. Average Oil Share 1977-1980 is the share of the oil and mineral extraction sectors in GSP by state, averaged over 1977-1980; this regressor is transformed to $\log (1+$ share $)$ in order to dampen outliers and avoid zero observations. Retirees/Population 1980 is the share of retirees in state population in 1980. A constant is included in all specifications. Heteroskedasticity robust $t$-statistics in parentheses. 
Figure 1: Output/Income Ratio, U.S. Regions
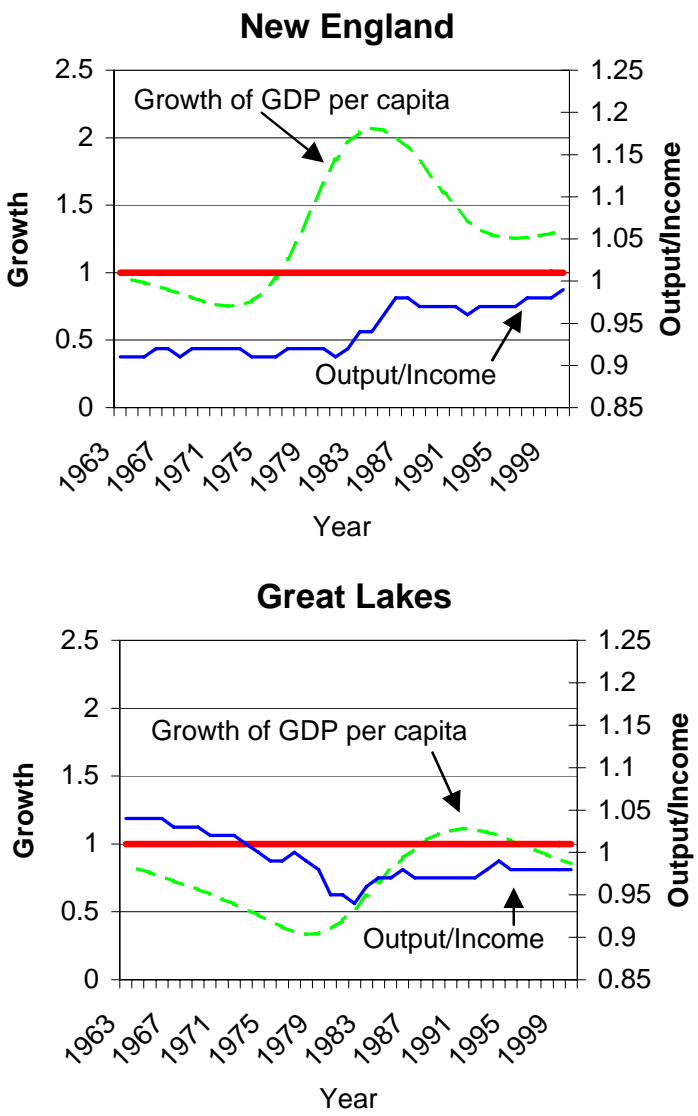

South East

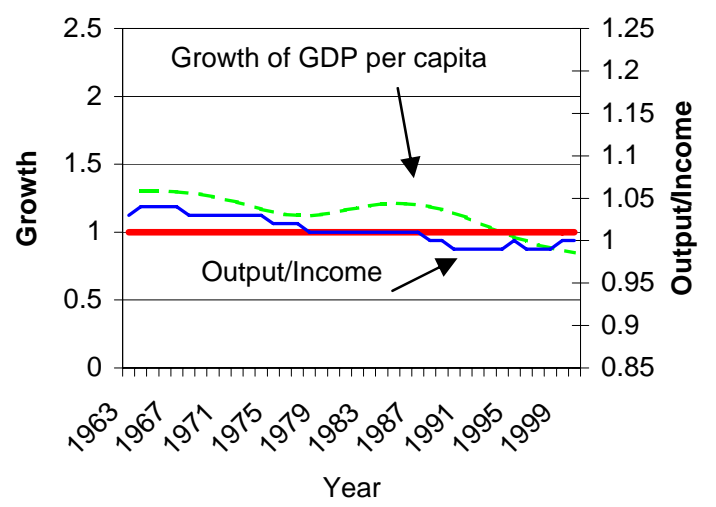

Rocky Mountains

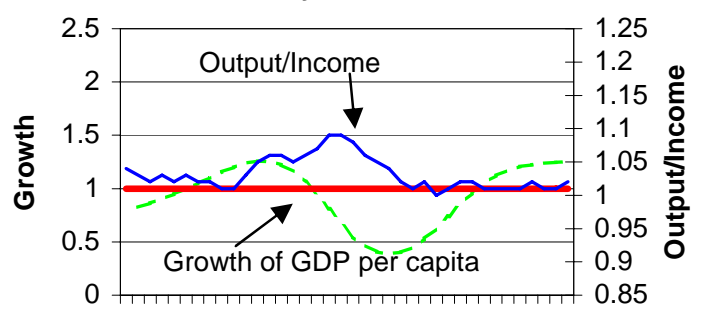

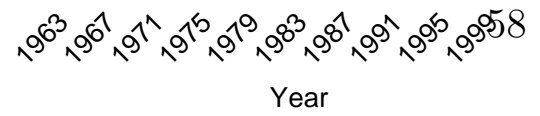
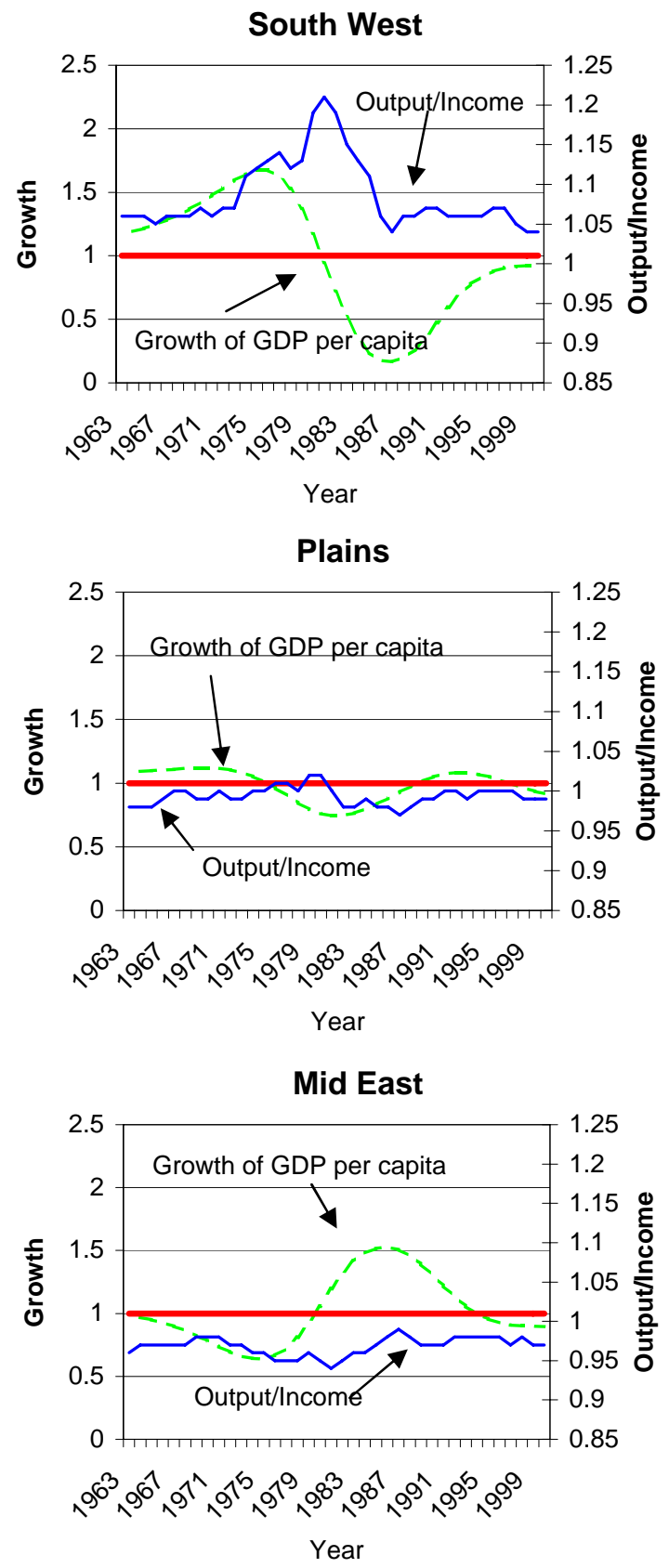

Far West

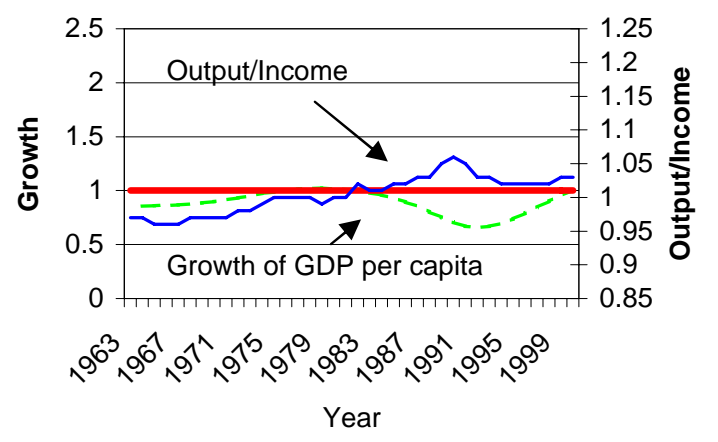


Figure 2: Output/Income Ratio, Oil Regions

Average Output/Income for Alaska, Louisiana and Wyoming, versus World Real Price of Crude Oil

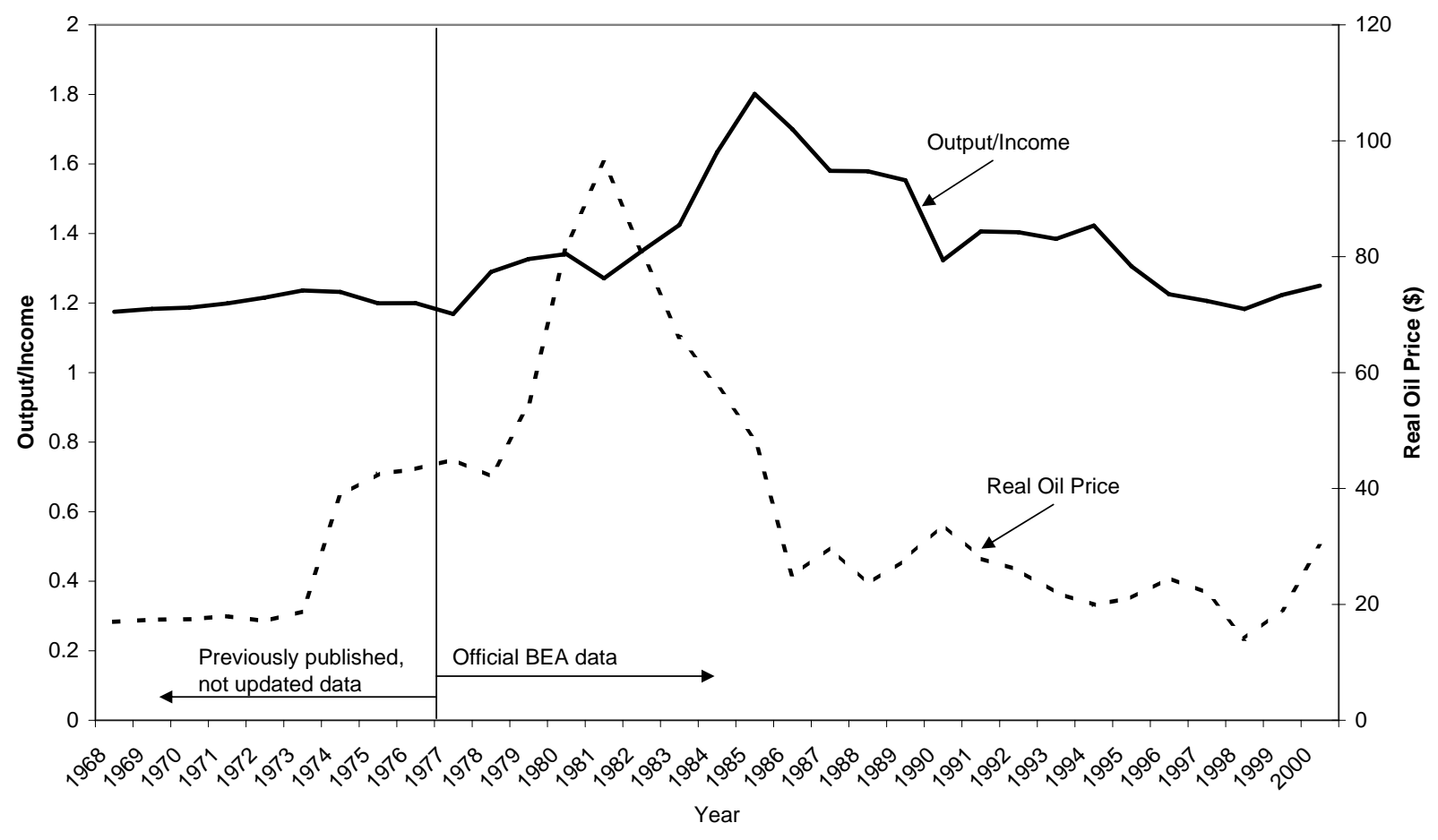

